\title{
PENGEMBANGAN MODEL PARAMETRIK METODE DEA DALAM MENGUKUR TINGKAT EFISIENSI BIAYA PADA PERBANKAN SYARIAH DI KOTA SEMARANG
}

\author{
Willyanto Kartiko Kusumo, Abdul Karim \\ Economics Faculty, Semarang University
}

\begin{abstract}
Efficiency is one of the performance parameters that are theoretically is one of the underlying performance of the overall performance of an organization. Efficiency in the banking sector is one of the performance parameters are quite popular, widely used because it is a response to the difficulties in calculating measures of bank performance. Measurement of the efficiency of banking can be done with the development of non-parametric statistical model by using Data Envelopment Analysis (DEA). In general, there are three approaches to the basic concepts of financial sector efficiency model that is cost efficiency, standard profit efficiency and alternative profit efficiency. In this research method used is the Data Envelopment Analysis (DEA). In this method, profit is modeled to deviate from its efficient frontier profit due to random noise and inefficiency. Profit in this method is affected by the function of input and output, while input and output used in this study is the Third Party Funds, Capital paid, placements with Bank Indonesia. By using this method the efficiency of Islamic banking DEA during 2012 to 2015 experienced an annual average efficiency of $94.37 \%$ and profit Islamic banking is heavily influenced by the financing facilities and placements with Bank Indonesia.
\end{abstract}

Keywords: Efficiency, financial performance, Islamic Banking, Data Envelopment Analysis (DEA).

1.

\section{PENDAHULUAN}

\subsection{Latar Belakang Masalah}

Bank merupakan suatu lembaga yang berfungsi untuk memperlancar lalu lintas keuangan yang berpeangaruh pada mobilitas pertumbuhan perekonomian suatu Negara. Berdasarkan Undang-undang No.7 Tahun1992 tentang perbankan sebagaimana telah diubah dengan Undang-undang No.10 Tahun 1998, jenis bank di Semarang terdiri daridua kelompok yaitu bank umum dan Bank Perkreditan Rakyat (BPR). Dalam Undang-undang tersebut dijelaskan bahwa bank umum adalah bank yang melaksanakan kegiatan usaha secara konvensional dan atau berdasarkan prinsip syariah yang dalam kegiatannya memberikan jasa dalam lalu lintas pembayaran. Dalam menjalankan kegiatan usahanya, bank umum dapat memilih satu dari tiga pilihan yaitu seluruhnya beroperasi secara konvensional, seluruhnya beroperasi secara syariah, atau melakukan kegiatan usaha secara konvensional sekaligus juga melakukan kegiatan usaha berdasarkan prinsip syariah (dual banking system). Perbedaan yang mendasar antara bank syariah dengan bank konvensional adalah pada produk dan jasa perbankan yang ditawarkan serta cara 
pembagian keuntungannya. Jika bank konvensional menerapkan sistem bunga dan menghalalkan kegiatan yang diharamkan dalam Islam, berbeda dengan bank syariah yang memiliki karakteristik antara lain tidak menerapkan sistem bunga, menggunakan metode bagi hasil dan jual beli, hanya memberikan pembiayaan pada kegiatan usaha yang halal, dan bank syariah harus memiliki Dewan Pengawas Syariah (DPS). Sejarah perbankan syariah di Semarang dimulai dengan berdirinya Bank Muamalat Indonesia (BMI) pada tahun 1991 yang diprakarsai oleh Majelis Ulama Indonesia (MUI) dan pemerintah Indonesia.

Menurut Muharam dan Pusvitasari (2007:82), perbankan syariah tidak mengalami negative spread seperti yang dialami oleh perbankan konvensional pada umumnya. Hal ini dikarenakan kewajiban membayar bunga oleh bank kepada para nasabahnya akan selalu melekat pada bank apapun kondisinya. Pertumbuhan jumlah bank syariah selama periode 20092013 (5 tahun) terus mengalami peningkatan. Sedangkan jumlah bank konvensional justru mengalami penurunan selama periode pengamatan. Hal tersebut mengindikasikan bahwa perbankan syariah mampu berkembang dan dapat diterima denganbaik oleh masyarakat. Perkembangan yang cukup baik dan signifikan dari bank syariah berdampak pada jumlah aset bank tersebut.

\subsection{Rumusan Masalah}

Berdasarkan uraian diatas maka dalam penelitian ini akan diharapkan dapat diperoleh gambaran yang jelas mengenai Pengembangan Model Non-parametrik Metode Stochastic Frontier Approach (SFA), Data Envelopment Analysis (DEA) dan Distribution Free Approach (DFA) Dalam Mengukur Tingkat Efisiensi Biaya Pada Industri Perbankan Syariah Indonesia. Temuan ini sangat penting terutama dalam upaya memberikan informasi mengenai seberapa pentingkah tingkat efisiensi biaya pada perbankan syariah. Maka perumusan masalah dalam penelitian ini adalah :

1. Bagaimana tingkat efisiensi biaya industri perbankan Indonesia yang terdaftar berdasarkan pengembangan model parametrik dengan metode Stochastic FrontierApproach (SFA), Data Envelopment Analysis (DEA) dan Distribution Free Approach (DFA) dalam mengukur tingkat efisiensipada industri perbankan syariah Indonesia.

2. Apakah terdapat perbedaan nilai efisiensi antara Bank Umum Syariah, Unit Usaha Syariah dan Layanan Syariah (office channeling) dalam menjalankan aktivitas dan operasionalnya dilihat dari komponen input dan output apa yang sangat mempengaruhi tingkat efisiensi tersebut berdasarkan prinsip kehati-hatian yang tersirat dalam Undang-Undang Perbankan No. 10 tahun 1998 dan Cetak Biru Pengembangan Perbankan Syariah.

\subsection{Keluaran yang diharapkan}

Riset ini diharapkan dapat memberikan kontribusi untuk :

1. Menambahkan dukungan empiris mengenai tingkat efisiensi pada perbankan syariah Indonesia berdasarkan Metode pendekatan parametrik; Data Envelopment Analysis (DEA), sehingga diharapkan para pimpinan perusahaan perbankan syariah dapat digunakan sebagai salah satu sarana dalam menetapkan strategi usaha di waktu yang akan datang.

2. Dalam penelitian ini juga diharapkan dapat memberikan masukan kepada pemerintah, dalam hal ini Bank Indonesia, penilaian efisiensi perbankan dapat digunakan untuk menetapkan dan menerapkan strategi pengawasan yang tepat pada bank yang bersangkutan. Dan yang terakhir, tentunya bagi pihak masyarakat dengan mengetahui efisiensi perbankan diharapkan masyarakat akan merasa lebih tenang atau aman dalam 
menempatkan dananya di perbankan syariah, karena yakin bank akan mengelola dana tersebut dengan baik sesuai dengan prinsip-prinsip syariah.

\section{TELAAH PUSTAKA DAN PENGEMBANGAN MODEL}

\subsection{Konsep Efisiensi}

Efisiensi merupakan rasio antara output dan input, dan perbandingan antara masukkan dan keluaran. Apa saja yang dimaksudkan dengan masukan serta bagaimana angka perbandingan tersebut diperoleh, akan tergantung dari tujuan penggunaan tolak ukur tersebut. Secara sederhana menurut Nopirin (1997), efisiensi dapat berarti tidak adanya pemborosan. Konsep mikro ekonomi yaitu teori konsumen dan teori produsen. Teori konsumen mencoba untuk memaksimumkan kegunaan atau kepuasan dari sudut pandang individu, sedangkan teori produsen mencoba untuk memaksimumkan keuntungan atau meminimumkan biaya dari sudut pandang produsen.Pada teori ekonomi terdapat dua jenis efisiensi, yaitu efisiensi teknik (technical efficiency) dan efisiensi ekonomi (economic efficiency). Efisiensi ekonomi mempunyai gambaran ekonomi makro, sedangkan efisiensi teknik memiliki gambaran ekonomi mikro.

Efisiensi dalam perbankan syariah, seperti halnya perusahaan juga merupakan tolak ukur dalam mengukur kinerja bank. Dimana efisiensi merupakan jawaban atas kesulitan-kesulitan dalam menghitung ukuran-ukuran kinerja seperti tingkat alokasi, teknis, maupun total efisiensi (Hadad et al., 2003:2). Sedangkan menurut Haseeb Shahid et al. (2010:25), efisiensi perbankan syariah didefinisikan sebagai perbedaan antara jumlah variabel input dan output yang diamati dengan variabel input dan output yang optimal. Bank syariah yang efisien dapat mencapai nilai maksimum satu dan bank inefisien nilainya dapat berkurang sampai nol. Selain itu juga, Efisiensi industri perbankan syariah dapat ditinjau dari sudut pandang mikro maupun makro (Berger dan Mester, 1997 dalam Zaenal Abidin dan Endri, 2009:21). Dari perspektif mikro, dalam suasana persaingan yang semakin ketat sebuah bank syariah agar bisa bertahan dan berkembang harus efisien dalam kegiatan operasionalnya. Bank-bank syariah yang tidak efisien, besar kemungkinan akan exit dari pasar karena tidak mampu bersaing dengan kompetitornya, baik dari segi harga (pricing) maupun dalam hal kualitas produk dan pelayanan.Kondisi perbankan syariah yang tidak efisien juga akan kesulitan dalam mempertahankan kesetiaan nasabahnya dan juga tidak diminati oleh calon nasabah dalam rangka untuk memperbesar customerbasenya.

\subsection{Pengukuran Efisiensi}

Ada tiga jenis pendekatan pengukuran efisiensi khususnya perbankan, yaitu:

\section{Pendekatan Rasio}

Pendekatan rasio dalam mengukur efisiensi dilakukan dengan cara menghitung perbandingan output dan input yang digunakan. Pendekatan ini akan dapat dinilai memiliki efisiensi yang tinggi apabila dapat menghasilkan output yang semaksimal mungkin dengan input yang seminimal mungkin.

\section{Pendekatan Regresi}

Pendekatan ini dalam mengukur efisiensi menggunakan sebuah model dari tingkat output tertentu sebagai fungsi dari berbagai tingkat input tertentu. Pendekatan regresi akan menghasilkan estimasi hubungan yang dapat digunakan untuk memproduksi tingkat output yang dihasilkan sebuah Unit Kegiatan Ekonomi (UKE) pada tingkat input tertentu. UKE dapat dikatakan efisien apabila menghasilkan output lebih banyak dari pada output hasil estimasi. Kelemahan dalam pendekatan ini adalah ketidakmampuannya dalam menampung banyak output, karena dalam sebuah persamaan regresi hanya dapat 
menampung satu indikator output. Apabila dilakukan penggabungan banyak output dalam satu indikatormaka informasi yang dihasilkan menjadi tidak rinci lagi (Silkman, 1986 dalam Muharam dan Pusvitasari, 2007:87).

\section{Pendekatan Frontier}

Menurut Silkman (1986) dalam Muharam dan Pusvitasari (2007:87), pendekatan frontier dalam mengukur efisiensi dibedakan menjadi dua jenis yaitu pendekatan frontier parametrik dan non-parametrik.

\subsection{Konsep Efisiensi Metode Data Envelopment Analysis (DEA)}

Data Envelopment Analysis (DEA) dikembangkan pertama kali oleh Farrel (1957) yang mengukur efisiensi teknik satu input dan satu output menjadi multi input dan multi output, menggunakan kerangka nilai efisiensi relatif sebagai rasio input (single virtual input) dengan output (single virtual output) (Giuffrida dan Gravelle, 2001; Lewis et, al. 1999; Post dan Spronk, 1999 dalam Adrian Sutawijaya dan Etty Puji Lestari, 2009). Alat analisis ini dipopulerkan oleh beberapa peneliti lainnya, di antaranya (Adrian Sutawijaya dan Etty Puji Lestari, 2009):

\section{a. Charnes-Cooper-Rhodes (2008)}

Para peneliti ini pertama kali menemukan model DEA CCR (CharnesCooper-Rhodes) pada tahun 1978. Menurut Harjum Muharam dan Pusvitasari (2007), model ini mengasumsikan adanya Constant Return to Scale (CRS). CRS adalah perubahan proporsional yang sama pada tingkat input akan menghasilkan perubahan proporsional yang sama pada tingkat output (misalnya: penambahan 1 persen input akan menghasilkan penambahan 1 persen output).

b. Bankers, Charnes dan Cooper (2011)

Beberapa peneliti ini mengembangkan lebih lanjut model DEA BCC (Bankers, Charnes dan Cooper) pada tahun 1984. Harjum Muharam dan Pusvitasari (2007) menyebutkan bahwa model ini mengasumsikan adanya Variable Return to Scale (VRS). VRS adalah semua unit yang diukur akan menghasilkan perubahan pada berbagai tingkat output dan adanya anggapan bahwa skala produksi dapat mempengaruhi efisiensi. Hal inilah yang membedakan dengan asumsi CRS yang menyatakan bahwa skala produksi tidak mempengaruhi efisiensi. Teknologi merupakan salah satu faktor yang mempengaruhi VRS, sehingga membuka kemungkinan skala produksi mempengaruhi efisiensi. Analisis yang dilakukan berdasarkan evaluasi terhadap efisiensi relatif dari UKE yang sebanding, selanjutnya UKE-UKE yang efisien tersebut akan membentuk garis frontier. Apabila UKE berada dalam garis frontier, UKE tersebut dapat dikatakan efisien relatif dibandingkan dengan UKE lainnya dalam sampel. DEA juga dapat menunjukkan UKE-UKE yang menjadi referensi bagi UKEUKE yang tidak efisien (Ascarya, Diana Y. dan Guruh S. R., 2008). Ada tiga manfaat yang diperoleh dari pengukuran efisiensi DEA, yaitu (Insukirdo, dkk 2000 dalam Adrian Sutawijaya dan Etty Puji Lestari, 2009) :

a. Sebagai tolak ukur untuk memperoleh efisiensi relatif yang berguna untuk mempermudah perbandingan antara unit ekonomi yang sama.

b. Mengukur berbagai variasi efisiensi antar unit ekonomi untuk mengindentifikasi faktor-faktor penyebabnya.

c. Menentukan implikasi kebijakan, sehingga dapat meningkatkan nilai efisiensinya.

Pada awalnya, DEA digunakan untuk mengatasi kekurangan yang dimiliki oleh analisis rasio dan regresi berganda. Analisis rasio hanya mampu memberikan informasi bahwa UKE tertentu yang memiliki kemampuan khusus mengkonversi satu jenis input ke satu jenis output tertentu, sedangkan analisis regresi berganda menggabungkan banyak output menjadi satu. DEA dirancang 
untuk mengukur efisiensi relatif suatu Unit Kegiatan Ekonomi (UKE) yang menggunakan input dan output yang lebih dari satu, di mana penggabungan tersebut tidak mungkin dilakukan (Adrian Sutawijaya dan Etty Puji Lestari, 2009). Adapun kelemahan dan kelebihan DEA :

a. Keunggulan DEA, meliputi:

1. Dapat menangani banyak input dan output.

2. Tidak perlu asumsi hubungan fungsional antara variabel input dan output.

3. Unit Kegiatan Ekonomi (UKE) dibandingkan secara langsung dengan sesamanya.

4. Input dan output dapat memiliki satuan pengukuran yang berbeda.

b. Kelemahan DEA, yaitu:

1. Bersifat sample specific (DEA berasumsi bahwa setiap inpu atau output identik dengan unit lain dalam tipe yang sama).

2. Merupakan extreme point technique.

3. Kesalahan pengukuran dapat berakibat fatal.

4. Hanya untuk mengukur produktivitas relatif dari Unit Kegiatan Ekonomi (UKE) bukan produktivitas absolut.

5. Uji hipotesis secara statistik atas hasil DEA sulit dilakukan.

\subsection{Hubungan Input dan Output dalam Pengukuran Efisiensi Bank}

Perhitungan efisiensi dengan menggunakan metode parametrik membutuhkan suatu pendugaan fungsi biaya sebagai frontier untuk mengetahui tingkat efisiensi suatu bank. Tetapi sebelum menentukan fungsi biaya yang digunakan, input dan output dari bank harus ditentukan terlebih dahulu. Input pada perbankan syariah terdiri dari tiga pihak. Dana pihak pertama adalah berasal dari dana yang berasal dari para pemodal, pemegang saham. Dana pihak kedua adalah dana yang berasal dari pinjaman lembaga keuangan (bank dan bukan bank), pinjaman dari Bank Indonesia. Dana pihak ketiga adalah dana yang berasal dari dana simpanan, tabungan, dan deposito. Setelah input terkumpul di bank, selanjutnya bank syariah dapat menghasilkan output. Output tersebut berupa penyaluran dana kepada pihak yang membutuhkan dalam bentuk pembiayaan, kredit dan jasa. Dalam hal ini, ada beberapa pendekatan dalam penentuan variabel input dan output dari bank antara lain Intermediary Approach, User-Cost Approach, dan Value Added Approach.Intermediary Approach adalah penentuan variabel input dan variabel output dengan memperhatikan fungsi bank sebagai lembaga intermediasi. Dalam hal ini, terdapat 3 pendekatan yang lazim digunakan baik dalam metode parametrik Stochastic Frontier Analysis (SFA) dan Distribution Free Analysis (DFA) maupun non-parametrik Data Envelopment Analysis (DEA) untuk mendefinisikan hubungan input dan output dalam kegiatan finansial suatu lembaga keuangan, yaitu:

a. Pendekatan Aset. Produksi aset mencerminkan fungsi primer sebuah lembaga keuangan sebagai pencipta kredit pinjaman (loans). Pendekatan ini, output didefinisikan ke dalam bentuk aset.

b. Pendekatan Produksi. Pendekatan ini menganggap lembaga keuangan sebagai produsen dari akun deposito (deposit account) dan kredit pinjaman (credit accout), kemudian output didefinisikan sebagai jumlah tenaga, pengeluaran modal pada aset-aset tetap dan material lainnya.

c. Pendekatan Intermediasi. Pendekatan ini memandang sebuah lembaga keuangan sebagai intermediator, yaitu merubah dan mentransfer aset-aset keuangan dari surplus unit kepada defisit unit. Inputinput lembaga keuangan tersebut meliputi: biaya tenaga kerja, modal dan pembayaran bunga pada deposito, kemudian output 
yang diukur dalam bentuk kredit pinjaman (loans) dan investasi keuangan (financial investment). Pendekatan ini melihat fungsi primer sebuah institusi keuangan sebagai pencipta kredit pinjaman (loans).

Konsekuensi terdapat tiga pendekatan dalam mengukur efisiensi bank adalah perbedaan untuk menentukan input dan output. Perbedaan penentuan input dan output antara pendekatan produksi dan intermediasi adalah dalam memperlakukan simpanan. Simpanan sebagai output pada pendekatan produksi, dikarenakan simpanan merupakan jasa yang dihasilkan oleh kegiatan bank. Pendekatan intermediasi menganggap simpanan sebagai input. Hal ini disebabkan simpanan yang dihimpun bank akan ditransformasikan ke dalam berbagai bentuk aset yang menghasilkan terutama pinjaman yang diberikan. Penelitian ini menggunakan pendekatan intermediasi, karena sejalan dengan pendapat Ahmad Syakir Kurnia (2004) yang mengungkapkan bahwa pendekatan intermediasi digunakan karena mempertimbangkan fungsi vital bank sebagai financial intermediation yang menghimpun dana dari surplus unit dan menyalurkannya kepada deficit unit. Pendekatan intermediasi merupakan pendekatan yang lebih tepat untuk mengevaluasi kinerja lembaga keuangan syariah secara umum karena karakteristik lembaga keuangan sebagai financial intermediation yang menghimpun dana dari surplus unit dan menyalurkan kepada deficit unit. Dengan menggunakan pendekatan intermediasi ini juga diharapkan dapat menggambarkan fungsi perbankan yang sesungguhnya. Ditambahkan menurut Iqbal dan Molyneux (2005) dalam Bader et. al (2008:33) pendekatan intermediasi lebih unggul untuk mengevaluasi frontier efficiency dalam profitabilitas lembaga keuangan.

\section{METODE PENELITIAN}

\subsection{Jenis dan Sumber Data}

Penelitian ini adalah merupakan penelitian pengujian hipotesis atau penelitian penjelasan (explanatory research). Data yang digunakan dalam penelitian ini adalah data sekunder berupa laporan keuangan daribulan Januari2010 sampai dengan Desember 2013 yang diperoleh dari pojok Bursa Efek Indonesia Universitas Semarang (USM), Universitas Diponegoro (Undip), website Bank Indonesia dan Pusat Informasi Pasar Modal (PIPM) Cabang Semarang. Sedangkan obyek penelitian ini adalah bank yang menganut prinsip syariah (bagi hasil) baik itu Bank Umum Syariah (BUS) ataupun Unit Usaha Syariah (UUS) di Semarang dan tidak termasuk BPRS.

\subsection{Lokasi Penelitian}

Penelitian ini mengambil obyek pada bank yang menganut prinsip syariah (bagi hasil) yang berjumlah 37 Bank, yang terdiri dari: 11 Bank Umum Syariah (BUS), 10 Unit Usaha Syariah (UUS), dan 16 Layanan Syariah (Office Chanelling) tidak termasuk Bank Perkreditan Rakyat Syariah (BPRS). Data ini diambil dari direktori yang berasal dari Bank Indonesia.

\subsection{Peubah Yang diamati}

Peubah yang diamati dalam penelitian ini adalah sebagai berikut :

1. Penempatan pada Bank Indonesia (PBI). Penempatan Bank Indonesia merupakan saldo rekening giro bank syariah dalam rupiah maupun valuta asing di Bank Indonesia. (Muhammad, 2004; 123)

2. Penempatan pada Bank Lain (PBL). Penempatan pada Bank Lain (PBL) adalah penanaman dana pada bank syariah lain baik di dalam maupun di luar negeri dalam bentuk antara lain Sertifikat Investasi Mudharabah Antar Bank, deposito mudharabah, tabungan mudharabah, giro wadiah, dan tabungan wadiah yang dimaksud untuk optimalisasi pengelolaan dana. (Muhammad, 2004; 123) 
3. Biaya Tenaga Kerja. Biaya Tenaga Kerja ini diperoleh dari laporan keuangan tahunan Bank Umum Syariah, Unit Usaha Syariah dan yang bersangkutan selama periode pengamatan.

4. Pembiayaan yang Diberikan (PD). Pembiayaan ini merupakan penyediaan dana dan/atau tagihan berdasarkan akad mudharabah dan/atau musyarakah dan/atau pembiayaan lainnya berdasarkan prinsip bagi hasil.

5. Total Kredit. Total Kredit ini diperoleh dari neraca dalam laporan keuangan bank umum syariah dan total pembiayaan dari neraca dalam laporan keuangan Bank Umum Syariah, Unit Usaha Syariah selama periode pengamatan.

6. Total Pendapatan. Total Pendapatan diperoleh dari laporan laba/rugi dalam laporan keuangan tahunan Bank Umum Syariah, Unit Usaha Syariah dan berbagai Layanan Syariah yang bersangkutan selama periode pengamatan.

7. Total Simpanan.Cara memperoleh Total Simpanan berasal dari laporan keuangan tahunan Bank Umum Syariah, Unit Usaha Syariah dan berbagai Layanan Syariah yang bersangkutan selama periode pengamatan.

8. Total Aset Bank. Total Aset Bank Syariah diperoleh dari neraca dalam laporan keuangan tahunan Bank Umum Syariah, Unit Usaha Syariah yang bersangkutan selama periode pengamatan.

9. Dana Pihak Ketiga (DPK). Dana Pihak Ketiga merupakan penjumlahan dari Giro Wadiah, Tabungan Mudharabah, dan Deposito Mudharabah.

10. Modal Disetor (MDs)

Modal Disetor adalah modal yang telah efektif diterima bank sebesar nilai nominal saham.

11. Efisiensi adalah kemampuan perbankan syariah dalam menghasilkan laba dengan input dan output yang telah ditetapkan dan diukur secara relatif menurut waktu.

\subsection{Model yang digunakan}

Dalam penelitian ini digunakan perhitungan efisiensi perbankan syariah dari sisi profit dengan menggunakan metode pendekatan Alternative Profit Efficiency sedangkan untuk perhitungannya menggunakan metode pendekatan Data Envelopment Analysis (DEA). Metode Data Envelopment Analysis (DEA) merupakan sebuah metode frontier non-parametrik yang menggunakan model program linier untuk menghitung perbandingan rasio output dan input untuk semua unit yang dibandingkan dalam sebuah populasi (Abidin dan Endri,2009:25). Perhitungan Data Envelopment Analysis (DEA) ini akan dibantu dengan paket-paket software efisiensi secara teknik, seperti Banxia Frontier Analysis (BFA), Warwick for Data Envelopment Analysis (WDEA), dan Max DEA. Penelitian ini akan menggunakan bantuan software Max Data Envelopment Analysis (Max DEA). Pada intinya software-software tersebut akan menunjukkan pada hasil yang sama. Analisis Data Envelopment Analysis (DEA) pada awalnya digunakan untuk mengatasi kekurangan analisis rasio dan regresi berganda, dimana Data Envelopment Analysis (DEA) dapat mengukur efisiensi relatif suatu UKE (Unit Kegiatan Ekonomi) dengan menggunakan input dan output lebih dari satu. Efisiensi relatif suatu UKE (Unit Kegiatan Ekonomi) adalah efisiensi suatu Unit Kegiatan Ekonomi dibandingkan dengan UKE (Unit Kegiatan Ekonomi) lain dalam sampel yang menggunakan jenis input dan output yang sama. Data Envelopment Analysis (DEA) memformulasikan UKE (Unit Kegiatan Ekonomi) sebagai program linear fraksional untuk mencari solusi, apabila model tersebut ditransformasikan ke dalam program linear dengan nilai bobot dari input dan output. Penelitian ini menggunakan variabel-variabel input yang meliputi: pertama, simpanan yang 
berarti jumlah dana masyarakat yang dihimpun oleh bank syariah. Kedua, aset milik bank syariah. Ketiga, biaya tenaga kerja/personalia didefinisikan sebagai biaya gaji dan tunjangan kesejahteraan, biaya pendidikan karyawan bank syariah. Asumsi dengan metode DEA dalam penelitian ini menggunakan Constant Return to Scale (CRS). Model orientasi output juga akan diterapkan dalam penelitian ini. Proses perhitungan dengan ketiga metode tersebut dilakukan dengan memisahkan antara bank syariah yang tergolong Bank Umum Syariah (BUS) dengan bank syariah yang termasuk Unit Usaha Syariah dan Layanan Syariah.

\subsection{Rancangan Penelitian \\ 1. Jenis data}

Data yang digunakan adalah data sekunder, yaitu data yang diperoleh dari informasi yang dipublikasikan oleh Bank Indonesia bersifat kuantitatif yang menekankan pada pengujian teori-teori melalui pengukuran variabel-variabel penelitian dan melakukan analisis data dengan prosedur statistik. Penelitian ini dilakukan dengan melihat laporan keuangan dari Bank Indonesia dan Bank Umum Syariah, Unit Usaha Syariah dan berbagai Layanan Syariah/Office Chanelling yang bersangkutan selama periode pengamatan.

\section{Populasi dan Sampel}

Populasi dalam penelitian ini adalah Bank Unit Syariah (BUS), Unit Usaha Syariah (UUS) dan Layanan Syariah (Office

\subsection{Analisis Data}

Penelitian ini akan mengukur efisiensi perbankan syariah dengan menggunakan metode DEA dengan pendekatan intermediasi, mengingat peran vital perbankan sebagai lembaga intermediasi. Analisis ini kemudian akan menghasilkan perumusan frontier interaksi antar input dalam mempengaruhi jumlah output yang dihasilkan. Hubungan input dan output tersebutlah yang kemudian
Chanelling) yang terdaftar di Bank Indonesia. Pengambilan sampel dalam penelitian ini dilakukan secara purposive sampling yaitu metode pemilihan sampel dipilih berdasarkan pertimbangan (judgement sampling) yang berarti pemilihan sampel secara tidak acak dimana informasinya diperoleh dengan pertimbangan tertentu. Kriteria sampel yang digunakan dalam penelitian ini adalah sebagai berikut:

1. Bank syariah yang beroperasi di Semarang yang berskala nasional selama periode pengamatan, tidak termasuk Bank Perkreditan Rakyat (BPR) dan Bank Perkreditan Rakyat Syariah (BPRS)

2. Sampel bank syariah adalah 11 Bank Umum Syariah, 24 Unit Usaha Syariah (UUS) dan 31 Layanan Syariah (Office Channeling) dengan jumlah aset terbesar yang telah terdaftar di Bank Indonesia selama periode pengamatan dengan menyajikan laporan keuangan yang telah dipublikasikan oleh Bank Indonesia.

\subsection{Teknik Pengumpulan Data}

Metode pengumpulan data dalam penelitian ini yang dilakukan adalah dengan menggunakan data-data keuangan kepada 37 sampel perbankan syariah atau memperoleh informasi yang meliputi : penempatan pada Bank Indonesia, penempatan pada bank lain, biaya tenaga kerja, pembiayaan yang diberikan, total kredit, total pendapatan, total simpanan, total aset, dana pihak ketiga dan modal disetor.

akan menentukan nilai efisiensi, sehingga akan dapat dilihat perbedaan antara efisiensi Bank Umum Syariah (BUS), Unit Usaha Syariah (UUS) dan Bank yang berbasis pada Layanan Syariah (Office Channeling). Asumsi dalam penelitian ini menggunakan Constant Return to Scale (CRS). Setelah sampel terpilih, selanjutnya mengumpulkan data-data yang lengkap dan setelah data terkumpul dan dimasukkan dengan menggunakan frontier analysis maka selanjutnya dilakukan 
pengukuran efisiensi teknik dengan tiga dapat ditampilkan gambar kerangka metode tersebut. Untuk lebih jelasnya, maka konseptual penelitian berikut ini :

INPUT

\begin{tabular}{|ll|}
\hline 1. & Biaya Dana \\
2. & Biaya Tenaga Kerja \\
3. & Dana Pihak Ketiga (DPK) \\
4. & Modal Disetor (MDS) \\
\hline
\end{tabular}

\section{OUTPUT}

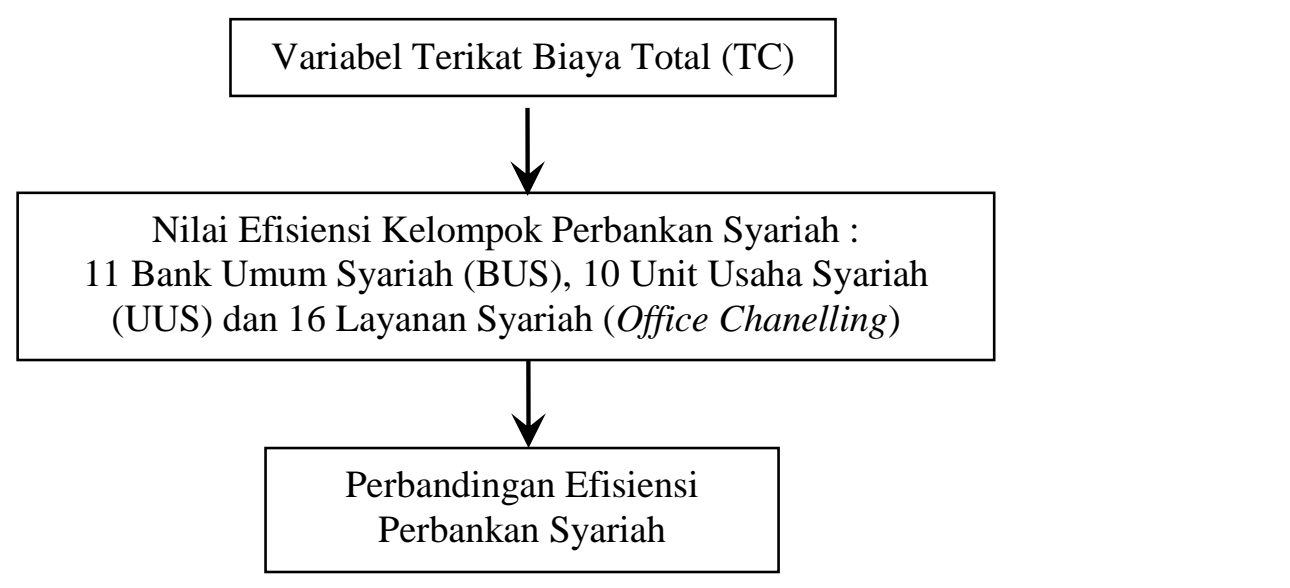

1. Kredit

2. Sekuritas

3. Penempatan pada Bank Indonesia

4. Penempatan pada Bank Lain (PBL)

5. Pembiayaan yang Diberikan (PD)

\section{Gambar 1 \\ Kerangka Konseptual Penelitian}

\section{ANALISIS DATA DAN PEMBAHASAN}

\subsection{Deskripsi Umum}

Pada bab iniakan dipaparkan mengenai hasil penelitian secara empiris dengan pengujian dan perhitungan secara statistik untuk mengukur tingkat efisiensi perbankan syariah dengan periode pengamatan yang digunakan adalah dari tahun 2012 sampai dengan tahun 2015. Perhitungan efisiensi dilakukan secara panel data pada 4 periode tahunan. Dengan metode pendekatan DEA untuk menghitung tingkat efisiensi pada perbankan syariah di Semarang. Dalam penelitian ini, efisiensi bank syariah didasarkan pada kemampuan bank syariah menghasilkan profit (laba) dari input dan output yang digunakan, sehingga istilah laba ataupun efisiensi di dalam penelitian ini adalah memiliki makna yang sama. Sedangkan output (Y) yang digunakan pada penelitian ini adalah penempatan pada Bank Indonesia, penempatan pada bank lain, pembiayaan yang diberikan. Sedangkan input (X) yang digunakan adalah Dana Pihak Ketiga (DPK terdiri dari giro wadiah, tabungan mudharabah, dan deposito mudharabah), dan modal disetor. Efisiensi dalam penelitian ini didasarkan pada fungsi biaya, dengan cara mempertimbangkan biaya total (total cost) sebagai variabel dependen serta 2 buah variabel output yaitu total pinjaman yang diberikan baik kepada pihak terkait dengan bank maupun tidak terkait dengan bank (Q1) dan surat berharga yang 
dimiliki oleh bank (Q2) dengan 2 buah variabel input yaitu total biaya bunga yang dibayarkan bank atas simpanan pihak ketiga (P1) dan biaya tenaga kerja (P2). Semua variabel disajikan dalam bentuk rasio terhadap total aktiva. Sebelum melakukan pembahasan terhadap efisiensi bank, akan disajikan kondisi dari variabel selama tahun 2012 sampai dengan tahun 2015.

\subsection{Statistik Deskriptif}

Deskripsi dari masing-masing variabel penelitian selanjutnya dapat dilihat pada tabel 1.berikut ini :

Tabel 1.

StatistikDeskriptif

\begin{tabular}{lllrlr}
\hline & \multicolumn{1}{c}{ Variabel } & Mean & Std.Dev & Min & Max \\
\hline Dependen & Total Cost & 0.09282 & 0.02508 & 0.04912 & 0.19269 \\
Output & Kredit yang diberikan & 0.50888 & 0.14310 & 0.16570 & 0.75378 \\
& Surat berharga & 0.08075 & 0.10477 & 0.00018 & 0.48967 \\
& Penempatan Pada BI & 0.09172 & 0.41744 & 0.71542 & 0.02498 \\
& Penempatan Bank Lain & 0.08173 & 0.56172 & 0.61743 & 0.02947 \\
Input & Pembiayaan Diberikan & 0.12986 & 0.41732 & 0.52893 & 0.03176 \\
& Biaya Dana & 0.05298 & 0.01569 & 0.03095 & 0.11224 \\
& Biaya Tenaga Kerja & 0.01456 & 0.00691 & 0.00361 & 0.04098 \\
& Dana Pihak Ketiga & 0.04998 & 0.02579 & 0.03195 & 0.12264 \\
& Modal Disetor & 0.03156 & 0.04291 & 0.03615 & 0.16072 \\
\hline
\end{tabular}

Sumber : Data sekunder yang diolah.

Total biaya (TC) selama tahun 2012 hingga 2015 menunjukkan nilai rata-rata sebesar 0,09282 dengan standar deviasi sebesar 0,02508. Nilai rata-rata sebesar 0,09282 menunjukkan bahwa total biaya yang dikeluarkan oleh keseluruhan bank adalah sebesar 0,09282 atau 9,282\% dari seluruh aktiva yang dimiliki bank. Total biaya (TC) selama tahun 2012 hingga 2015 menunjukkan nilai rata-rata sebesar 0,09282 dengan standar deviasi sebesar 0,02508. Nilai rata-rata sebesar 0,09282 menunjukkan bahwa total biaya yang dikeluarkan oleh keseluruhan bank adalah 9,282\% dari seluruh aktiva yang dimiliki bank.

\subsection{Analisis Tingkat Efisiensi Perbankan Dengan menggunakan metode} Stochastic Frontier Analysis (SFA) model cross section, tingkat efisiensi dapat diukur dan dibandingkan secara relatif antar pengamatan. Output yang diproxy dari total pinjaman yang diberikan baik kepada pihak terkait dengan bank maupun tidak terkait dengan bank (Q1) dan surat berharga yang dimiliki oleh bank (Q2), sedangkan variabel input menggunakan total biaya bunga atas simpanan pihak ketiga (P1) dan biaya tenaga kerja (P2). Pada tahun 2011 nilai signifikasinya sebesar 0,011 dimana nilai ini lebih kecil dari tingkat kepercayaan $5 \%$. Berarti terdapat perbedaan yang signifikan pada nilai efisiensi ketiga kelompok perbankan pada tahun 2011. Nilai signifikasi pada tahun 2012 sebesar 0,152 dan pada tahun 2013 sebesar 0,128 kedua nilai ini lebih besar dari tingkat kepercayaan 5\% sehingga nilai efisiensi pada ketiga kelompok bank pada tahun 2012 dan 2013 tidak terdapat perbedaan yang signifikan.

\subsection{AnalisisVarian(ANOVA)}

Untuk menguji ada tidaknya perbedaan yang terjadi dari estimasi tingkat efisiensi bank dari kelompok Bank Umum Syariah, Unit Usaha Syariah dan Layanan Syariah 
akan diuji dengan uji Anova. Hasil pengujian diperoleh sebagai berikut:

Tabel 2.

Hasil Uji Anova

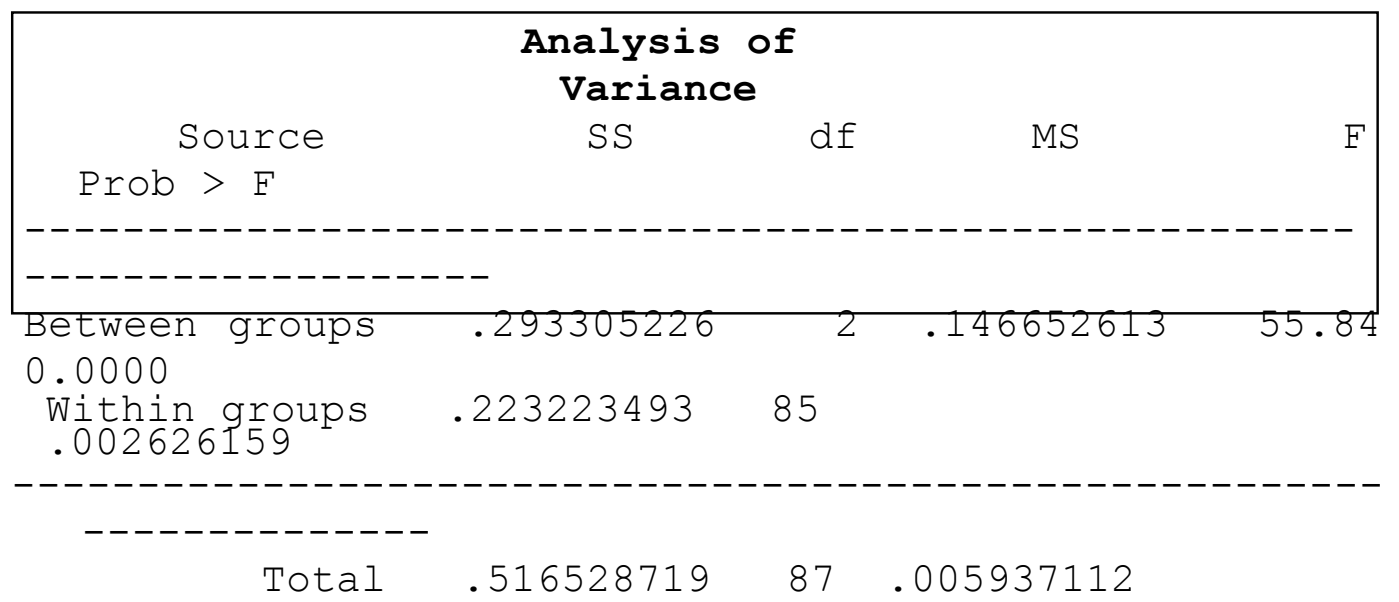

Dari hasil analisa nilai uji perbedaan tingkat efisiensi berdasarkan kelompok bank diperoleh nilai $\mathrm{F}$ sebesar 55,84 dengan $\mathrm{p}=0,000<0,05$. Hal ini berarti $\mathrm{H} 1$ diterima yang berarti pula terdapat perbedaan efisiensi yang signifikan pada ketiga kelompok perbankan syariah di Semarang.

\subsection{Pengujian Variabel}

\section{Uji Koefisien Determinasi (R2)}

Secara statistik untuk mengetahui pengaruh variabel-variabel bebas (variabel independen) secara serentak terhadap variabel tidak bebas (variabel dependen) dapat dilihat dari besarnya koefisien korelasi ganda atau R. Besarnya koefisien determinasi adalah 0,5379 yang menunjukkan variabel bebas mempengaruhi variabel tidak bebas sebesar 53,79\% sisanya sebesar $46,21 \%$ dipengaruhi oleh variabel lain yang tidak dimasukkan dalam model penelitian. Artinya variabel input dan output yang dimasukkan (Dana Pihak Ketiga, Modal disetor, Penempatan pada Bank Indonesia, penempatan pada bank lain, dan Pembiayaan yang diberikan) mempengaruhi laba perbankan syariah

sebesar 53,79 \% dan sisanya sebesar 46,21\% dipengaruhi variabel lain.

\section{Uji Serentak (Uji F)}

Untuk mengetahui signifikansi pengaruh semua variabel independen secara bersama-sama terhadap variabel dependen digunakan Uji F. Uji F digunakan untuk melihat signifikansi pengaruh antara variabel independent atau variabel bebas secara serentak terhadap variabel dependent atau variabel terikat yaitu dengan membandingkan Fhitung yang dihasilkan oleh regresi linear berganda dengan $\mathrm{F}_{\text {tabel }}$ pada taraf signifikan sebesar 95\% ( $\alpha=5 \%)$. Hasil uji F diperoleh Fhitung sebesar 9,7778 lebih besar dari Ftabel dengan N1 (k1) $=4$ dan $\mathrm{N} 2$ (n-k) = 43 maka didapat FTabel 2,61. Karena Fhitung lebih besar dari Ftabel maka $\mathrm{H}_{0}$ ditolak dan H1diterima, atau dapat diartikan bahwa secara serentak (bersama-sama) variabel input dan output (Dana Pihak Ketiga, modal disetor, penempatan pada BI, penempatan pada bank lain, dan pembiayaan diberikan) berpengaruh terhadap laba pada perbankan syariah di Semarang.

\section{Uji Parsial (Uji t)}

Uji Parsial (Uji t) digunakan untuk 
menguji kuatnya hubungan masing-masing variabel independen dengan variabel dependen terhadap laba. Sedangkan analisis dari hasil uji parsial (uji t) dimaksudkan untuk membuktikan dari penelitian yang menyatakan masing-masing variabel independent (Y) dan variabel dependen (X) mempunyai pengaruh terhadap laba $(\pi)$. Dengan membandingkan antara nilai tabel dengan thitung yang didapat dari masingmasing variabel dengan menggunakan taraf signifikan 95\% $(\alpha=5 \%)$. Dengan derajat kebebasan $(\mathrm{DF}=\mathrm{N}-\mathrm{k}-1=48-5-1=42)$ diperoleh tabel sebesar $\pm 1,684$. Dengan membandingkan tabel dan thitung dalam tabel 2. diatas dapat dilihat bahwa secara individu ada variabel yang tidak signifikan mempengaruhi laba perbankan syariah dan ada yang signifikan mempengaruhi laba perbankan syariah di Semarang.

\subsection{Pembahasan Hasil Penelitian}

Dengan metode pendekatan DEA dan alternative profit efficiency secara umum Perbankan Syariah selama tahun 20122015 telah mengalami efisiensi rata-rata sebesar 94,3698 \%. Hal ini didasarkan pada waktu dimana bank mengalami laba maksimal dalam periode waktu yang diteliti yaitu pada bulan Desember 2015. sehingga periode ini digunakan sebagai pembanding terhadap efisiensi perbankan syariah pada periode sebelumnya. Hal ini sesuai dengan penelitian yang telah dilakukan oleh Astiyah yang menyebutkan bahwa secara total efisiensi adalah sebesar 91,4\% dan $92,4 \%$. Walaupun secara umum perbankan syariah di Semarang mengalami rata-rata efisiensi $94,3698 \%$, namun jika dilihat nilai

\section{KESIMPULAN DAN SARAN}

\subsection{Simpulan}

Berdasarkan analisa efisiensi perbankan syariah di Semarang dengan metode pendekatan SFA dengan data efisiensi dengan menggunakan periode yang paling efisien tiap tahunnya maka didapatkan hasil yang berbeda dengan efisiensi apabila dilihat dari keseluruhan periode yang diteliti.Dengan menggunakan metode penghitungan yang mendasarkan periode yang paling efisien dari masingmasing tahun didapakan hasil yang berbeda dengan menggunakan metode penghitungan yang mendasarkan periode yang paling efisien dari tahun 2012 sampai tahun 2015. Perbedaan ini terjadi karena perbedaan besarnya nilai yang digunakan sebagai pembagi, dimana pada penghitungan seluruh periode pembaginya adalah pada bulan Desember 2015 dan pada penghitungan efisiensi pertahun pembaginya adalah periode yang paling efisien dari tiap tahunnya (Desember). Masing-masing tahun tentunya mempunyai nilai pembagi yang berbeda (lebih kecil kecuali untuk tahun 2015). Secara umum efisiensi perbankan syariah mengalami peningkatan. Namun jika dilihat efisiensi tiap bulannya mengalami fluktuasi (naik turun). Pertumbuhan efisiensi dari tahun 2012 sampai dengan tahun 2015 tertinggi terjadi pada bulan Desember 2014 yaitu 2,96\% dari bulan November 2014, sedangkan pertumbuhan paling rendah terjadi pada bulan Mei2014 sebesar $-2,99 \%$ dari bulan Februari. Akan tetapi jika dibandingkan dengan bulan yang sama pada tahun sebelumnya, pertumbuhan efisiensi tertinggi pada bulan April 2013 naik sebesar $8,84 \%$ dari periode yang sama pada tahun 2012 (86,93\% menjadi 94,14\%), sedangkan pertumbuhan terendah terjadi pada bulan September 2014 yang turun sebesar 2,88 \% dari periode yang sama pada tahun 2013 (95,71\% menjadi 92,96\%).

penelitian yang digunakan adalah data bulanan mulai tahun 2010 sampai dengan tahun 2013 dan menggunakan variabel input dan otput secara berurutan yaitu dana pihak ketiga (DPK), modal disetor (MDS), penempatan 
pada Bank Indonesia (PBI), penempatan pada bank lain (PBL), dan pembiayaan yang diberikan (PD). Dapat disimpulkan sebagai berikut :

1. Berdasarkan data yang ada variabel biaya dana dan biaya tenaga kerja yang merupakan komponen input, selama tahun pengamatan 2010 sampai dengan tahun 2013, diperoleh bahwa kelompok Layanan Syariah (Office Chanelling) lebih kecil dibandingkan dengan kelompok Bank Umum Syariah (BUS) dan kelompok Unit Usaha Syariah (UUS). Dari data variabel kredit yang diberikan dan surat berharga yang dimiliki oleh bank yang merupakan komponen output selama tahun pengamatan 2010 sampai dengan tahun 2013. Kelompok Layanan Syariah (Office Chanelling) paling besar, kemudian kelompok Unit Usaha Syariah (UUS) dan yang paling kecil kelompok Bank Umum Syariah (BUS).

2. Berdasarkan hasil analisis Cross Section Stochastic Frontier Analysis nilai efisiensi perbankan syariah di Semarang menunjukkan angka-angka yang hampir mendekati $100 \%$. Hal ini menunjukkan adanya tingkat efisiensi relatif antar bank dalam sampel pengamatan yang tinggi yang telah dilakukan oleh kelompok perbankan syariah. Selain itu juga, kelompok perbankan syariah di Semarang setelah dianalisis menggunakan model Cross Section SFA selama 4 tahun pengamatan, diperoleh hasil dari tahun 2010 sampai dengan tahun 2013 bagi kelompok Layanan Syariah (Office Chanelling) menempati nilai efisiensi yang paling tinggi, kemudian kelompok Unit Usaha Syariah (UUS) dan nilai terkecil pada kelompok Bank Umum Syariah. Dari Ketiga kelompok tersebut selama tahun 2010 sampai dengan tahun 2013 mengalami penurunan nilai efisiensinya. Pada Tahun 2013 kelompok Layanan Syariah (Office Chanelling) mengalami peningkatan nilai efisiensi yang tinggi. Tahun 2013 kelompok Layanan Syariah (Office Chanelling) nilai efisiensinya tertinggi kemudian kelompok Bank Umum Syariah (BUS) dan terakhir kelompok Unit Usaha Syariah.

3. Berdasarkan pengamatan pada tiap kelompok bank, diperoleh bahwa jenis Layanan Syariah selama pengamatan Tahun 2010 sampai dengan tahun 2013 cenderung menghasilkan efisiensi yang paling tinggi kemudian kelompok Unit Usaha Syariah dan terakhir kelompok Bank Umum Syariah menunjukkan efisiensi yang paling rendah.

4. Secara umum efisiensi perbankan syariah di Semarang selama periode yang diteliti (Januari 2010 sampai dengan periode Desember 2013) mengalami peningkatan, tetapi untuk beberapa bulan efisiensi perbankan syariah mengalami penurunan, yaitu pada bulan April 2010, Juni dan Oktober 2011, Mei dan Oktober 2012, Maret, Juli, dan Oktober 2013.

\subsection{Implikasi Kebijakan}

Implikasi teoritis yang dapat diperoleh dari penelitian ini adalah:

1. Hasil penelitian ini menyatakan bahwa terdapat perbedaan yang signifikan nilai efisiensi berdasarkan kelompok perbankan syariah. Hal ini sesuai dengan penelitian Ansari (2006) yang menyatakan bahwa bank-bank secara signifikan berbeda nilai efisiensinya.

2. Hasil penelitian ini menyatakan bahwa kelompok Layanan Syariah (Office Chanelling) memiliki nilai efisiensi yang paling tinggi, kemudian Unit Usaha Syariah (UUS) dan Bank Umum Syariah (BUS) dengan nilai efisiensi yang paling rendah. Penelitian ini sesuai dengan penelitian Bonin (2003) dan Fries (2004) yang menyatakan bahwa bank milik pemerintah tergolong tidak efisien 
3. dibandingkan dengan bank-bank swasta domestik dan bank swasta asing.

Sedangkan untuk Implikasi manajerial yang dapat diperoleh dari penelitian ini adalah :

1. Berdasarkan hasil pengamatan data penelitian variabel biaya tenaga kerja yang merupakan komponen input kelompok Bank Umum Syariah (BUS) selama tahun pengamatan Tahun 2010 sampai dengan tahun 2013, paling tinggi dibandingkan dengan kelompok dan kelompok Unit Usaha Syariah (UUS), hal ini sebaiknya kelompok Bank lebih mengoptimalkan komponen input berupa biaya tenaga kerja untuk memperoleh output yang optimal.

2. Pihak manajemen Bank Umum Syariah (BUS) perlu bekerja keras untuk mengoptimalkan seluruh potensi yang ada. Kedepan pendapatan dari hasil pemberian kredit harus lebih besar dibandingkan pendapatan bunga obligasi pemerintah karena dari data variabel kredit yang diberikan kelompok Bank Bank Umum Syariah (BUS) selama tahun pengamatan lebih rendah dibandingkan dengan kelompok Unit Usaha Syariah (UUS) maupun kelompok Layanan Syariah (Office Chanelling).

3. Efisiensi merupakan tolok ukur utama bagi Bank agar dapat dikatakan sebagai bank sehat. Adapun langkah-langkah yang perlu dilakukan adalah mengurangi jumlah utang baik itu jangka pendek maupun jangka panjang dalam rangka memperkuat modal Bank. Perlunya mengoptimalkan sumber daya manusia yang ada. Dari kesimpulan diatas ada beberapa saran yang penulis ingin sampaikan, diantaranya adalah :

1. Dana pihak ketiga dan Modal disetor hendaknya dapat dikendalikan, karena dana pihak ketiga dan modal disetor dalam perbankan syariah selama ini memberikan dampak negatif terhadap laba yang diperoleh bank. Hal ini dapat disebabkan oleh banyaknya dana pihak ketiga dan modal yang masuk tetapi pembiayaan yang diberikan tidak seimbang, sehingga bagi hasil yang diterima perbankan tidak seimbang dengan beban bagi hasil yang harus diberikan kepada nasabah yang akhirnya dapat mengurangi laba yang akan diperoleh bank syariah.

2. Untuk mendapatkan laba yang maksimal, perbankan syariah di Semarang seharusnya lebih meningkatkan pembiayaan yang diberikan karena pembiayaan ini berpengaruh besar terhadap laba yang diperoleh perbankan syariah selama ini. Pembiayaan yang diberikan ini memiliki elastisitas sebesar 2,8271.

3. Selain pembiayaan yang diberikan, penempatan pada Bank Indonesia juga berpengaruh terhadap laba yang diperoleh perbankan syariah di Semarang dan mengurangi dana pihak ketiga, modal disetor, dan penempatan pada bank lain. Sedangkan Penempatan pada Bank Indonesia memiliki elastisitas 0,7186 dan Pembiayaan diberikan memiliki elastisitas 2,8271 .

\section{DAFTAR REFERENSI}

Abidin, Zaenal dan Endri. 2011."Kinerja Efisiensi Teknis Bank Pembangunan Daerah: Pendekatan Data Envelopment Analysis (DEA)". Jurnal Akuntansi dan Keuangan. Vol.11 No. 1 Hal 21-29.

Afif Amrillah, Muhammad. "Efisiensi 
Perbankan Syariah di Semarang Tahun 2005-2009".Tesis S2 Fakultas Ilmu Ekonomi dan Studi Pembangunan Universitas Diponegoro. 2013.

Arafat, Wilson. 2010. Manajemen Perbankan di Indonesia (Teori dan Implementasi). Jakarta: Pustaka LP3ES.

Ascarya, Diana Yumanita. 2009.“ Comparing The Efficiency of Islamic Banksin Malaysia and Indonesia". Buletin Ekonomi Moneter dan Perbankan, Tim IAEI. Hal 95-119.

Bank Indonesia. 2012. Statistik Perbankan Indonesia. http://www.bi.go.id. Diakses tanggal 4 Mei 2013.

Bank Indonesia. 2012. Statistik Perbankan Syariah. http://www.bi.go.id.Diakses tanggal 4 Mei 2013.

Cetak Biru Pengembangan Perbankan Syariah di Semarang. 2000

Coelli T.J, A Guide to DEAP Version 2.1: A Data Envelopment Analysis (Computer) Program, No 8/96. Centre For Efficiency and Productivit y Analysis Department of Econometric University of New England Armidale, NSW, 2351. Australia. 2009.

Endri. 2011. "Evaluasi Efisiensi Teknis Perbankan Syariah di Semarang: Aplikasi two stage data envelopment analysis". STEI Tazkia.

Fahmi, Irham dan Yovi Lavianti. 2010. Pengantar Manajemen Perkreditan. Bandung: Alfabeta.

Hadad, Muliaman D., dkk. 2013. Pendekatan Parametrik Efisiensi Perbankan Indonesia. http://www.bi.go.id. Diakses tanggal 7 Mei 2014.

Hadinata, Ivan dan A. H Manurung. 2009. "Penerapan Data Envelopment Analysis Untuk Mengukur Efisiensi Kinerja Reksa Dana Saham".

Huri, M. D. dan Indah Susilowati. 2004. "Pengukuran Efisiensi Relatif Emiten
Perbankan Dengan Metode Data Envelopment Analysis (DEA)". Jurnal Dinamika Pembangunan, Vol. 1 No 2 Hal 95-110.

Majid, A.M, dkk. 2012.'Efficiency in Islamic and Conventional Banking: an International Comparison". J Prod Anal 34:25-43.

Mardiah, Siti, Dkk. 2012. "Analisis Kinerja Bank Pemerintah dan Swasta Dengan Metode EVA dan MVA Terhadap Return Saham". Akuntabilitas, Hal 97-104. Jakarta

Mokhtar, Hamim. S A, et al. 2012. "Efficiency of Islamic Banking in Malaysia: A Stochastic Frontier Approach". Journal of Economic Cooperation, Vol. 27 ,No.2, Hal 37-70. Malaysia.

Mokhtar, Hamim. S A, et al. 2011. "Efficiency and Competition Of Islamic Banking in Malaysia". Humanomics, Vol 24 No 1 hal 28-48.

Muhamad, Shamsher, dkk. 2012. "Efficiency of Conventional versus Islamic Banks: International Evidence using the Stochastic Frontier Approach (SFA)". Journal of Islamic Economics, Banking and Finance, Hal. 107-130.

Muhamad, Shamsher, dkk. 2013. "Efficiency of Conventional versus Islamic Banks: International Evidence using the Data Envelopment Analysis (DEA)". Journal of Islamic Economics, Banking and Finance, Hal. 23-65.

Nisfiannoor, Muhammad. 2013. "Pendekatan Statistika Modern untuk Ilmu Sosial". Salemba Humanika: Jakarta

Qureshi, Muhammad Azeem. 2012. "Efficiency of Islamic and Conventional Banks in Pakistan: A Non-parametric Approach". International Journal of Bussiness and Mangement. Vol 7 No.7. Hal 40-50.

Riyadi, Selamet. 2010. "Banking Assets and Liability Management, Edisi 3. Jakarta: Lembaga Penerbit Fakultas Ekonomi Universitas Indonesia. 